\title{
ANALYSIS OF CODE SWITCHING USED IN STUDENT-LECTURER INTERACTIONS IN ONLINE LEARNING USING WHATSAPP
}

\author{
Nona Arlita Yuningsih ${ }^{1}$, Muhammad Amin ${ }^{2}$, Lalu Jaswadi Putera ${ }^{3}$ \\ Mataram University \\ lalujaswadi1981@gmail.com
}

\begin{abstract}
This study focuses on how code switchings (CS) are used in the student-lecturer interaction in Whats App-based online learning. It specifically aims at investigating the types, the functions, and the most dominant types of CS used in the so-called interaction. 233 code-switched utterances from the students' and the lecturer's chats were collected as the primary source data. The chats took place during the online learning of the Academic Vocabulary and Corpus course from March to November 2020. For data analysis, the types of CS proposed by Poplack and the functions of CS by Eldridge and Flyman-Mattsson/Burenbut were endorsed. The results show that the analyzed data contain 3 types of code-switching that included tag switching (21 uses, 9\%), intra-sentential switching (197 uses, 85\%), and intersentential switching (15 uses, $6 \%)$. Intra-sentential switching is the most dominant type found in the conversation. During the interaction, the lecturer applied 3 functions of CS that included topic switch (46\%), affective function (23\%), and repetitive function (31\%). Meanwhile, the students applied 4 functions of CS that included equivalence (28\%), floorbolding (2\%), reiteration (52\%), and conflict-control (18\%).
\end{abstract}

Keywords: Sociolinguistics; Code-switching; Bilingualism; Multilingualism.

\section{INTRODUCTION}

In communication, the relation between language and society cannot be separated. The study about the relation of language and society is called Sociolinguistics. Sociolinguistics is concerned with investigating the relationship between language and society with the goal of having a better understanding of the structure of language and of how languages function in communication. The equivalent goal in the sociology of language is trying to discover how social structure can be better understood through the study of language, for instance, how certain linguistic features serve to characterize particular social arrangements. 
According to Longman Dictionary, “interaction" means a process by which two or more things affect each other, the activity of talking to other people, working together with them, etc. These definitions mean that interaction is the action between people which influences each other. Generally, in this global era, it is often found that in the conversation, bilingual and multilingual speak to define a social status. The phenomenon of people having more than one code (language) is called bilingualism or multilingualism. Bilingualism is a situation where a speaker can use two languages as well. Bilingualism caused by four factors, namely, migration, imperialism, federation, and border area. These factors prompt bilingual society to switch languages. The phenomenon of bilingualism results in the occurrence of code switching.

Code Switching is the communicative strategy used by interacting bilingual speakers; using more than one variety or language in the same conversation. Code Switching can be found in classroom instruction used by teachers. Teacher who uses code switching may start a lesson in English language and move into the second language. This way, they want to ensure that the lesson is as communicative as possible. As it is the case for teachers' code switching, the students also are not always aware of the reasons for code switching as well as its functions and outcomes. Although they may unconsciously perform code switching, it clearly serves some functions either beneficial or not.

This study, therefore, focuses on investigating the types, the functions, and the most dominant types of code switching used in conversation between the students and the lecturer on WhatsApp. Data were the conversations of the fourth semester students of the English department enrolling in the Academic Vocabulary and Corpus course of the academic year 2019/2020. By having this topic, it is believed that the types and the functions of code switching in classroom instructions by the lecturers and the students can be identified and classified. 


\section{LITERATURE REVIEW}

\section{Previous Studies}

Cakrawarti (2011) conducted a study entitled "Analysis of Code Switching and Code Mixing in the Teenlit Novel Canting Cantiq by Nuranindiya". The study confirmed that there were 6 types of code switching (CS) and code mixing (CM) that included: intra-sentential switching, inter-sentential switching, emblematic switching, intra-lexical code mixing, establishing continuity with the previous speaker, and involving a change of pronunciation. Many of the dialogues in the novel are expressed in English, Bahasa Indonesia, and the local language(s). The most dominant type of CS and CM was intra-sentential switching. She also found 10 causes of the use of CS and CS with "expressing group identity" as the most dominant one.

The next study entitled "English Code Switching and Code Mixing on Television Advertisements and Its Contributions to Language Teaching" (Norlaili, 2012) aimed to find out the types and the reasons of using CS and CM based on Hoffman's and Scotton's theories, and the contribution of CS and CM to language teaching. The results suggested that there were 3 types of code-switching and 3 types of code-mixing found in the private Indonesian television advertisements that included. The types of code-switching were intra sentential switching, inter sentential switching, and tag switching; and the types of code mixing were intra sentential mixing, involving a change, and intra lexical mixing. The study also found 7 reasons why code switching and code mixing were used in television advertisements, those were, to talk about topic, to express solidarity, to make interjection, to make repetition, to clarify the speech of content, to express group identity, to soften or strengthen request, and solely for the lexical need.

The last study carried out by Wirda (2011) entitled “English Teachers' Code Switching: in the Drive for Maximum Use of English (A Descriptive Study of 10th Grade English Teacher of SMAN 7 Semarang in the Academic Year of 2010/2011” focused on investigating the frequency, the factors, and possible factors of teachers using code switching in face-to-face classroom context by applying descriptive qualitative method using library and field research. The results confirmed that there 
were 6 functions of classroom code-switching, those were, insufficient vocabulary resources, affective function, emphasis, elaboration, addressee specification, and clarification. From all functions, emphasis function was the most dominant that comprises more than $50 \%$ times. The possible factors were: natural phenomenon to code-switch English into Indonesian as the first language to overcome misconception or misunderstanding between the teacher and students, underscoring the material to improve students understanding in receiving the materials.

In view of the substantial connections, despite sharing some similarities with the previous studies in terms of the objectives and the methods used, the current study differs mostly with the three in regards to the objects of the research. The gap that had attracted the researchers to further conduct a study on the relevant topic. While Cakrawarti (2011), Norlaili (2012), and Wirda (2011) used novel, television ads, and teacher-student in-class interaction as the objects of their studies, respectively, the present study investigated the interaction between the students and the lecturer on an online learning context using social media.

\section{Bilingualism}

Bilingualism is a situation when two or more language used alternately by the same speaker, it can be said that those languages contact each other. Chaer and Agustina (2004) stated that bilingualism means the use of two languages by a speaker in his society by turns. It is common to college, school or even boarding house use bilingualism in daily communication. So, the students must master mother tongue and another language that become a second language. People usually speak languages they master in daily use. For example, Indonesian people when they speak with their family. When they know more than one language, they may use both of which in their conversation, for example in the school and office. People use more than one language that occurs in situation of social context, which is a situation where they learn a second language in their communities. One also needs to distinguish between bilingual communities where everyone has mastery of two languages (although mostly differently categorized and even perhaps stigmatized) and individual bilingualism when a single person grows up bilingual living in a monolingual 
community; as in the case of the present study and of most studies concerning bilingual language acquisition (Genesee, 1989); Genesee, Nicoladis \& Paradis, 1995).

\section{Code Switching}

Code switching is a communication that uses more than one language in conversation. Likhitphongsathorn and Sappapan (2013) define CS as a means of communication involving a speaker alternating between one language and another at the level of sentence. It is to move from one code (language, dialect, or style) to another during speech for a number of reasons such as: to signal solidarity, to reflect one's ethnic identity, to show off, to hide some information from a third party, to achieve better explanation of a certain concept, to converge or reduce social distance with the hearer, to diverge or increase social distance or to impress, and persuade the audience

Meanwhile Gal as cited in (Wardaugh, 2006) points out that CS is a conversational strategy used to establish, cross or destroy group boundaries; to create, evoke or change interpersonal relations with their right and obligation. From definition above it can be concluded that CS is a communicative strategy that is used in bilingual or multilingual communities by using more than one language in conversation.

\section{Types of Code Switching}

To complicate the definition of code switching further, various terms have also been used to describe switches between languages in conversation such as borrowing (Poplack, 1980), alternation (Muysken, 2000) and code-mixing (Myers-Scotton, 1992). Muysken (2000) proposes three categories of code switching: insertion, alternation and congruent lexicalization. Insertion is code switching similar to borrowing. It happens when the lexical items or entire constituents are inserted into a structure from the other language. It is different from borrowing in the sense that the size and type of element inserted is smaller, e.g. noun versus noun phrase. In the next 
process, alternation happens when there is a true switch from one language to the other, involving both grammar and lexicon. Thus, it usually occurs between turns or utterances. Lastly, when two languages share a grammatical structure which can be filled lexically with elements from either language that is congruent lexicalization. Below are some examples which can differentiate these three categories:

$\begin{array}{lll}\text { 1. Insertion } & \text { Do you want to eat } & \text { Do you want to eat spaghetti } \\ & \text { spaghetti or nasi lemak? } & \text { or coconut cream rice? } \\ \text { 2. Alternation } & \text { Saya nak pergi ke pasar, do } & \text { I want to go to the market, do } \\ & \text { you want to come along? } & \text { you want to come along? } \\ \text { 3. Congruent } & \text { Bila you nak hantar } & \text { When do you want to submit } \\ \text { lexicalization } & \text { homework? } & \text { your homework? }\end{array}$

Poplack (1980) distinguishes Code Switching occurrence within the same turn into three types: tag-switching, inter-sentential switching, and intra-sentential switching. Tag-switching is a minimal kind of switching which involves the insertion of a tag or marker from one language into a stretch of speech in another language. Inter-sentential switching involves switching languages at the clause boundary or between speaker turns. Intra-sentential switching differs from inter-sentential switching by involving switches within the clause or phrase.

\section{Functions of Code Switching}

The teacher uses code switching by starting the lesson in the English language and may move into the second language. This ensures that the lesson is as communicative as possible. Mattson and Burenhult (1999) listed the functions of CS used by teachers as topic switch, affective functions, and repetitive functions. Topic switch occurs when the teacher alters his/her language according to the topic that is under discussion. Affective function is used by teacher in order to build solidarity 
and intimate relation with the students. Repetitive function is used by the teacher to transfer the necessary knowledge for the students for clarity.

As it is the case for teachers' code switching, the students also are not always aware of the reasons for code switching as well as its functions and outcomes. Although they may unconsciously perform code switching, it clearly serves some functions either beneficial or not. Eldridge names these functions as: equivalence, floor-holding, reiteration, and conflict control. Equivalence is used by student for elicitation of equivalent item; using native lexical item when having no competence for using the target language, explanation for a particular lexical item. Floor-holding: wishing to continue without interruption. It is a mechanism used by students in order to avoid gaps in communication which may result from the lack of fluency in target language. Reiteration is a reinforcement, emphasis where the students repeat the message in native language from the target language through which the learner tries to give the meaning by making use repetition technique. Conflict-control is used by students to avoid potential conflicts or misunderstanding. The students will tend to utter words indirectly for specific purposes. 


\section{RESEARCH METHOD}

To attain the objectives of the study, the researchers used descriptive qualitative method. As stated by Maxwell (1996) that: "the strength as qualitative research derives primarily from its inductive approach, its focus on specific situation or people, and its emphasis on words rather the numbers". This method was used to describe the types and the functions of code-switching used by in student-lecturer interaction in online classroom interactions using WhatsApp.

The object of the research was the WhatsApp chats of the students of the English Education Program and their lecturer taking place during the Academic Vocabulary and Corpus (AVAC) course from March to November 2020. The participating students were registered in classes 4A and 4B: 34 students from Class $4 \mathrm{~A}$ and 29 students from Class 4B.

At the beginning, the researchers had planned to investigate code switching between students and the lecturer in face-to-face classroom interaction. (Un)Fortunately, the plan did not go as expected due to the Covid-19 pandemic that forced all universities in Indonesia to make a shift from face-to-face learning to online learning. Most of the universities required their lecturers to administer blended learning, a blend of synchronous and asynchronous learning or a blend of real-time video web meeting and non-video online learning. The real-time video web meeting consisted of 7 meetings and the non-video online learning also consisted of 7 meetings that comprise 16 meetings in total. The first half of the course were alocated for video web meeting platforms using either Zoom, Big Blue Button, Google Meet/Classroom, or Microsoft Teams, et cetera. Meanwhile the second half of the course were administered using whatever possible, cheaper, faster, badconnection free platforms like WhatsApp. The WhatsApp chat groups were used to share information/data, to submit assignments, to do presentations and discussions. The recorded WA conversations were then used as the primary data source of the research. Data were selected based on the research questions. In general, this study investigated codeswitching. In particular, it discussed the types and the functions of codeswitching in student-lecturer conversation in online learning class. 
This study utilized a non-participatory observation method for data collection. As stated by Sudaryanto (2015) that observation method is a method for collecting data by observing research objects in their context while non-participatory techniques is a type observation method to collect data without involving interaction with the participants. The researchers used this technique because they did not engage in interaction with the participants. Instead, they used the saved version of the WA chats from the lecturer in charge of the course and the WA groups. For the details about how to backup, copy, and save all the WA chats to email and convert them to Google Docs and PDF, visit https://opikini.com/cara-backup-chatwhatsapp-ke-email/ or other relevant sources.

For data analysis, the researchers used some procedures that included: transcribing the chats into written data, identifying data consisted of expressions, numbers, utterances, and code switching, classifying data based on categories that included: the types of code switching based on Poplack's theory (1980), functions of lecturer' code switching based on Flyman-Mattson's and Burenhult's theory (1999), and the functions of students' code switching based on Eldridge's theory (1996), describing an example(s) of each of the utterances based on its type and function of code switching, and finally drawing conclusion.

\section{FINDING AND DISCUSSION}

\section{Findings}

\section{Types of Code Switching and the Most Dominant Type}

As mentioned in the previous sections, Poplack (1980) distinguished code switching occurrence within the same turn into three types: tag-switching, intersentential switching, and intra-sentential switching. As shown in Table 1, the finding suggests that all subjects of the L1 and L2 utterances practice code-switching that consist of all the types mentioned by Poplack (1980), that is, tag switching, intersentential switching, and intra-sentential switching. 
Tabel 1. Distribution of the Types of Code Switching

\begin{tabular}{llllll}
\hline \multirow{2}{*}{ No. } & Types of Code-Switching & $\begin{array}{l}\text { Lecturer } \\
(\mathrm{L} 1)\end{array}$ & $\begin{array}{l}\text { Students } \\
(\mathrm{L} 2)\end{array}$ & $\begin{array}{l}\text { Total } \\
\text { Occurrence }\end{array}$ & Percentages \\
\hline 1 & Tag switching & 1 & 20 & 21 & $9.0 \%$ \\
\hline 2 & Inter-Sentential Switching & 3 & 12 & 15 & $6.4 \%$ \\
\hline 3 & Intra-Sentential Switching & 38 & 159 & 197 & $84.6 \%$ \\
\hline \multirow{2}{*}{ Total } & 42 & 191 & 233 & $100 \%$ \\
\hline
\end{tabular}

The finding also suggests that there are the highest and the lowest distribution of code switching in the student-lecturer interaction as shown in Table 1. Of the 233 expressions identified as having code-switching, intra-sentential switching occurred the most in the data comprising 197 occurrences or up to $80 \%$ of the total distribution. Meanwhile, tag switching is secondary with only 21 occurences or $9 \%$ of the total.

\section{Functions of Using Code-Switching}

Table 2 displays the functions of students code switching practiced in student-lecturer interaction on WhatsAppa. The finding suggests that the students practiced all four functions of code switching mentioned by Eldridge (1996), those are, equivalence, floor-holding, reiteration, and conflict control. Of the 85 total data, reiteration function distributes the highest number of occurences that comprises 44 occurences or $51.7 \%$. Meanwhile, the secondary one is floor-holding that comprises only $2.3 \%$ or 2 occurences in the data.

Table 2. Distribution of the functions of students' code switching

\begin{tabular}{llll}
\hline No. & Function types & Total Occurrence & Percentages \\
\hline 1 & Equivalent & 24 & $28.23 \%$ \\
\hline 2 & Floor-holding & 2 & $2.37 \%$ \\
\hline 3 & Reiteration & 44 & $51.76 \%$ \\
\hline 4 & Conflict control & 15 & $17.64 \%$ \\
\hline Total & & 85 & $100 \%$ \\
\hline
\end{tabular}


Reiteration mostly helped the students reinforce, emphasize, or clarify a message(s) that has already been transmitted in one code, but not understood.

Table 3 depicts the functions of lecturer's code switching. It can be seen that the lecturer practiced code switching that consists of all the three functions mentioned by Flyman-Mattsson and Burenhult (1999), those are, topic switch, affective function, and repetitive function.

Table 3. Distribution of the Functions of Lecturer's Code Switching

\begin{tabular}{llll}
\hline No. & Function types & Total Occurrence & Percentages \\
\hline 1 & Topic switch & 12 & $46.1 \%$ \\
\hline 2 & Affective function & 6 & $23.1 \%$ \\
\hline 3 & Repetitive function & 8 & $30.8 \%$ \\
\hline Total & & 26 & $100 \%$ \\
\hline
\end{tabular}

Of the 26 utterances having code switching, the most function used by the lecturer is topic switch that comprises $46.1 \%$ or 14 occurences while affective function is the secondary one.

\section{Discussion}

\section{Examples of Code Switching Found in the Current Study}

This section discusses the selected examples of types and functions of code switching found in the student-lecturer interaction on WhatsApp.

\section{Types of Code Switching}

a. Tag switching

As shown in examples (1), (2), and (3), the students used tag switching e.g. "lockdown", "Part D", and "observation" at the end or in the middle of the utterances using L2 (English) before switches to L1 (the mother language). 
(1) Emang ga di lockdown masjidnya, Sir?

(2) Part D terakhir kan ya?

(3) Masak observation?

This indicates that a tag switching occurs when the lecturer inserts a short expression or "tag" from a different language at the end or in the middle of his utterances.

b. Inter-sentential switching

As shown in example (4), the lecturer uses inter-sentential switching in his utterance to greet students and to apologize.

(4) Good morning guys, Sorry. Ada technical error di laptop saya, soal yang dibuat terhapus di link. Sedang saya buat ulang. UTS kita tunda SENIN, JAM 4.00 sore ya. Sorry for the inconvenience.

In example (4), inter-sentential switching occurs when the lecturer's has completed a sentence in L2 (English) then switches to another language (L1) in the next sentence. It occurs at the sentence level where each sentence is in one language of his utterances.

c. Intra-sentential switching

As shown in examples (5), (6), and (7), the students use intra-sentential switching in their utterances to ask a question or make a statement. The switching is from L1 (Indonesia) to L2 (English) such as "disubmit", "writing deadlinenya", and "ternotice".

(5) Bisa disubmit?

(6) writing deadlinenya minta undur aja jadi.

(7) Tidak ternotice olehku wkwkwk. 
Each of the above sentences is called intra-sentential switching because the speaker inserts a phrase, a part of morphemes i.e. prefix and suffix in the second language in a single utterance or sentence. It means that the speaker uses phrase to switch his language in a single sentence.

\section{Functions of Code switching}

a. Functions of Student's Code Switching

\section{Equivalence}

Equivalence functions as a strategy for students to switch the target language into the mother tongue when they feel incompetence in explaining something. Sentence (8) below shows the student's use of equivalent functions.

(8) I will answer fitri's question. Seperti yang kita ketahui Makan itu kebutuhan dasar. semua makhluk hidup butuh makan, bukan persoalan ada antena dan sebagainya tapi namanya juga kebutuhan jadi mereka ada cara sendiri nyari makan. For example, dolphins, they get their food by helping the fishermans. They need to solve the problem in their life, persoalan makan juga termasuk jadi mereka punya kemampuan tersendiri untuk itu.

In this respect, the student is trying to use the target language (English) at the beginning of the utterance. He starts talking in L2 to introduce the topic of the uttenaces then switches to L1 instead of keep using English when he feels uneasy.

\section{Floor-holding}

In floor holding case, as shown in sentence (9), the student fills the stopgap in the target language with his native language structure.

(9) What do you mean coexist? If you mean that they live together in one place/house it can't but if you mean that they live to be mutual we think that it can. 
The underlying reason for using this function of code switching, as suggested by Sert (2005), is the students' difficulty to recall the correct target language structure or lexicon. By using this process the students try to evade gaps in conversation, which may arise from having bad command in the target language.

\section{Reiteration}

In reiteration case as pointed by Eldridge (as cited in Sert, 2005): "messages are reinforced, emphasized, or clarified where the message has already been transmitted in one code, but not understood". In this case, as shown in sentences (10) and (11), the code switched utterances in L2 are repeated by the student in L1 through which the student tries to deliver the messages by making use of a reiteration technique.

(10) Good. Having seringkali berdampingan dengan noun.

(11) Good afternoon sir. mohon maaf pak, minggu lalu, bukannya kita kuliah sesuai jam kuliah pak?

The reasons for this language switch case are two folds: first, they may not have conveyed the meaning accurately in L2; second, they may think that it is more relevant to code switch in order to point out the lecturer that the content is overtly tacit by them.

\section{Conflict control}

The last function of students' code switching is conflict control. In conflict control case, the student "...tends to avoid a misunderstanding or tends to utter words indirectly for specific purposes" (Sert, 2005). One of the underlying reasons for the preference to practise this type of code switching is the student's lack of some culturally equivalent words among L1 and L2 so that possible misunderstandings can be avoided.

(12) Good I am sorry. Common noun kan? kok tulisannya command noun, makanya saya gak fokus tadi. 
(13) Maaf pak, apa maksud dari "Option 1" pada Part 3?

As shown in sentences (12) and (13), it can be noticed that everytime the students ask questions to the lecturer about the topic, they begin by saying apologetic utterances meant to show some respect to the lecturer. This conflict control's purpose is to maintain the relationship between the students and the lecturer. Thus, conflict control is a switching strategy the students use to clarify the intended meaning and to avoid misunderstanding in the conversation.

b. Teacher functions of code switching

\section{Topic switch}

(14) Diskusikan satu satu dari Exercise 1. Cocokkan dengan jawaban audience. Mungkin ada yang punya pendapat lain. Setelah selesai pindah ke Exercise 2 dan seterusnya.

As shown in sentence (14), the lecturer alters his language to L1 of his students in dealing with particular grammar points being taught at that moment. The lecturer tends to switch his code in the process of delivering material related to a certain topic.

\section{Affective function}

(15) Guys, kalau dimulai dengan kata a/the berarti itu NOUN, bukan ADJECTIVE atau VERB.

(16) Come on guys. Materinya gampang banget lo.

Affective function case as shown in sentence (15) and (16) are thrown to the students that are meant to amuse the students. By using this mechanism, the lecturer aims at creating an enjoyable situation in the teaching and learning process, breaking the ice, as well as building friendship and solidarity with the students. 
Repetitive function

(17) JUMLAH YG SUBMIT KLS 4A pagi 32 orang

(18) Submit bukan Sumbit. Gak konsen.

(19) Yang sudah SUBMIT pasti masuk di data saya. Don't worry.

The example of repetitive function case as shown in sentences (17), (18), and (19), The lecturer switches his code for the clarify of his statement or explanation regarding the unclear information about the previously stated explanation that makes the students get confused. Using this repetitive mechanism, the lecturer tries to make clear of himself to the students about his explanation. Alternating the code functions as an emphasis of what message of information the teacher is trying to convey.

\section{CONCLUSION}

As a final point, there are 3 types of CS based on Poplack's theory (1980) found in the student-lecturer interaction on WhatsAppa that included: tag switching (21), inter-sentential switching (15), and intra-sentential switching (197). Of the three, intra-sentential switching is the most dominant type of CS that comprises 197 uses or up to $80 \%$. Meanwhile, inter-sentential switching is the least type of CS used with only 15 uses or $6 \%$. Additonally, for the functions of students' code switching based on Eldridges theory (1996), there are 4 functions that are found in the data: equivalence (24), floor-holding (2), reiteration (44), and conflict control (15). The most dominant function of students' code switching is reiteration that comprises 44 uses $(52 \%)$ while floor-holding is the least function of code-switching among students with only $2 \%$. For the functions of lecturer's code switching based on Flyman-Mattson and Burenhult' theory (1999), the findings suggest that the 4 functions are topic switch (12), affective function (6), and repetitive function (8). The most function of code-switching practiced by the lecturer is topic switch that comprises 14 occurrences (46\%) took place in student-lecturer interaction on WhatsApp. 


\section{REFERENCES}

Cakrawarti, D. A. (2011). Analysis of code switching and code mixing in the teenlit Canting Cantiq by Dyan Nuranindya (Doctoral dissertation, University of Diponegoro). http:/ / eprints.undip.ac.id/27046/

Chaer, A., \& Agustina, L. (2004). Sosiolinguistik: Perkenalan awal. PT Rineka Cipta.

Denzin, K. Norman and Yvona S. Lincoln. (1994). Handbook of Qualitative Research, California: Sage Publications. p.1.

Eldridge, J. (1996). Code-switching in a Turkish secondary school. ELT Journal, 50/4:303-311.

Flyman-Mattsson, A., \& Burenhult, N. (1999). Code-switching in second language teaching of French. Working papers/Lund University, Department of Linguistics and Phonetics, 47, 59-72. https://bit.ly/3bHX6Mu.

Genesee, F. (1989). Early bilingual development: One language or two?. Journal of child language, 16(1), 161-179. http://bit.ly/3rbBLQK.

Genesee, F., Nicoladis, E., \& Paradis, J. (1995). Language differentiation in early bilingual development, Journal of Child Language, 22, 611-631. http://bit.ly/301GbOe.

Joseph Maxwell Alex. (1996). Qualitative Research Design, (London: SAGE Publication. p.17.

Likhitphongsathorn, T., \& Sappapan, P. (2013). A Study of English Code-mixing and Code-switching in Thai Pop Songs (Doctoral dissertation, Language Institute, Thammasat University). https://bit.ly/30OAOCh.

Muysken, P. (2000). Bilingual speech: typology of code-mixing. Cambridge, UK: Cambridge University Press.

Myers-Scotton, C. (1992). Comparing codeswitching and borrowing. Journal of Multicultural and Multilingual Development, 13, 19-40.

Norlaili, C. I. (2012). English Code Switching and Code Mixing in Television Advertisements And Its Contributions to Language Teaching (Doctoral dissertation, IAIN Walisongo). http://eprints.walisongo.ac.id/386/

Poplack, S. (1980). "Sometimes I" 11 start a sentence in Spanish y termino en Español: Toward a typology of code-switching." Linguistics vol. 18 pg.581- 618. http://bit.ly/3qHVF4N

Sert, O. (2005). The Functions of Code Switching in ELT Classrooms. The Internet TESL Journal, Vol. XI, No. 8, August 2005. http://iteslj.org/Articles/SertCodeSwitching.html/.

Sudaryanto. (2015). Metode dan aneka teknik analisis bahasa. Sanata Dharma University Press.

Wardhaugh. (1998). An Introduction to Sociolinguistics, Blackwell publisher, Oxford. 
Wardhaugh. (2006). An introduction to Sociolinguistics. Oxford, UK: Blackwell Publishing.

Wirda, A. (2011). English teacher's code-switching: in the drive for maximal use of English (a descriptive study of 10th grade English teacher of SMAN 7 Semarang in the academic year of 2010-2011)(Doctoral dissertation, IAIN Walisongo). https://bit.ly/3rLE1ys. 